\title{
Impact of a smoke-free policy on prisoners in Wisconsin, United States
}

\author{
Gianfranco Pezzino, Patrick L Remington, Henry Anderson, Paula M Lantz, \\ Dan E Peterson
}

\begin{abstract}
Objective-To assess the impact of restrictive smoking policies in prisons on prisoners' smoking attitudes and behaviours.

Design-A prospective observational study was carried out in a smoke-free prison and in a prison where smoking was allowed. Prisoners completed a questionnaire at the time of release. Smokers who declared that they would not smoke after leaving prison were followed up by telephone or letter 2-4 weeks later.
\end{abstract}

Subjects-376 prisoners leaving the smoke-free prison and 289 leaving the comparison prison after a stay of three or more days.

Main outcome measure-The likelihood that smokers leaving each prison were contemplating (planning or considering) to stop smoking. Among those contemplating stopping smoking, self reported smoking status was ascertained $2-4$ weeks after release.

Results-Smokers leaving the smokefree prison were about three times more likely than their counterparts in the comparison prison to contemplate stopping smoking (21\% v $7 \%, \mathrm{p}<0.001)$. Adjustment of the data for potential confounders did not change the results. Over $80 \%$ of those from both prisons who were contemplating stopping continued to smoke or resumed smoking within two weeks of release.

Wisconsin Division of Health, Bureau of Public Health, Madison, Wisconsin, USA

G Pezzino

P L Remington

$\mathrm{H}$ Anderson

P M Lantz

Centers for Disease

Control,

Epidemiology

Program Office,

Division of Field

Epidemiology,

Atlanta, Georgia,

USA

D E Peterson

Correspondence to: Dr G Pezzino, Wisconsin Division of Health, 1400 East Washington Avenue, 53703-3041, USA.

Introduction

In 1989 more than 10 million people were sent to prison in the United States, $43 \%$ of them for the first time. ${ }^{1}$ At any given time, almost 400000 adults are incarcerated in county jails
Prisoners often belong to segments of the population hard to reach with regular preventive programmes and health services, and their health problems are gaining increasing attention as an important public health issue. Particularly, the high rate of tobacco use in correctional institutions $(80 \%$ or more of adult prisoners $)^{2}$ is a concern for the health of both smokers and non-smokers. Cigarette smoking is known to contribute to heart disease and lung cancer, both leading causes of death among long term prisoners. ${ }^{3}$ There is also growing evidence of the negative health effects of environmental tobacco smoke (ETS) for non-smokers. ${ }^{4-6}$ In many correctional institutions problems with ETS are exacerbated by the combination of overcrowding, high numbers of smokers, and old buildings with poor ventilation systems. Cigarette use in correctional institutions may also increase the risk of fires.

The attitude of correctional institution administrators towards cigarette smoking has traditionally been very tolerant. ${ }^{7}$ In many cases tobacco has been distributed free or at a greatly reduced price, and cigarettes have been used as a reward for prisoners who perform special jobs or behave well. Cigarettes are frequently used as a form of currency that is bartered by prisoners. Their possession has been regarded as one of a prisoner's basic rights.

In recent years, however, law suits have been brought by non-smoking prisoners against jail and prison administrators to obtain a separation of the areas for smoking and nonsmoking inmates. ${ }^{8}$ One of these cases is now before the US Supreme Court. ${ }^{9}$ The American Medical Association has developed model legislation for smoke-free areas in prisons. ${ }^{10}$ These legal issues, coupled with concerns about fire hazards and the negative health consequences of smoking and of ETS, have prompted many jail and prison administrators to adopt smoking restrictions - and in some cases to ban smoking completely. A recent report from Wisconsin estimated that half of the jails in the state, housing $59 \%$ of all state prisoners, were or were planning to be completely smoke-free by the end of $1992 .{ }^{11}$

As a result of these restrictive or smoke-free and 700000 in state and federal prisons. ${ }^{1}$ policies, an increasing number of prisoners who smoke are required to undergo a sustained period of abstinence from smoking. However, little is known about the impact of this abstinence on their smoking behaviours after 
release. Therefore, we conducted a prospective observational study in two county jails, one with and one without a smoking ban, to examine attitudes about smoking cessation and smoking behaviours among prisoners who were smokers at the time of admission.

\section{Methods}

Dane County jail, located on two floors of a nine storey building in the centre of Madison (the state capital), recorded over 13000 admissions in 1990. The jail is usually overcrowded, with prisoners sleeping on the floors of the living areas. In August 1991 a full ban on any tobacco product and lighting material in the jail was adopted. Rock County jail, located in a modern building outside Janesville (about 40 miles south of Madison), recorded 5694 admissions in 1990. In Rock County jail inmates are allowed to smoke in the living area (where they can spend most of their daytime hours, from 0700 to 2100 ), but not in the sleeping areas. The two jails are located in neighbouring counties and their inmates come from several surrounding counties, with considerable overlap between the two.

Information on age, sex, race, employment status, reason for arrest, and length of stay was available from the jails' records. We developed a questionnaire to ask inmates about their smoking behaviour and their level of adaptation to the jail's smoking policy. Smokers were also asked whether they would like to stop smoking (if there were an easy way) and whether they were planning to stop smoking after leaving prison.

Questionnaires were distributed by the deputy sheriffs of the two jails to all inmates aged 18 or more who were released through the central booking office of each institution in October and November 1991. The inmates were asked to complete the form and return it before leaving. Questionnaires were not distributed to inmates released from court or through exits other than the central booking office. On the basis of the information obtained from the jail records, the age, sex, race, and reason for arrest of the inmates who were released from court or other exits (684 out of 1824 for Dane County and 474 out of 1052 for Rock County) did not differ significantly from those released through the central booking office.

An ever smoker was defined as someone who had smoked at least 100 cigarettes during his or her life. A current smoker was an ever smoker who smoked at the time of the arrest. To assess the impact of the smoking restriction after nicotine withdrawal, we limited our study to inmates who had been imprisoned for three or more days. We asked the current smokers who were leaving the jail the following questions: "Are you planning to smoke after you leave the jail?" and "Would you like to quit smoking, if there were an easy way?" Following Prochaska and $\mathrm{Di}$ Clemente, ${ }^{12}$ we defined contemplators as inmates who were smokers at the time of admission into the jail and either were planning to stop smoking after being released or were not sure whether they would stop, but would like to do so if there were an easy way. Those contemplating stopping were followed up by telephone (or by letter, when a telephone call was not successful) 2-4 weeks after their release and asked whether they had resumed smoking. Those who answered that they were not smoking were considered to be quitters at the time of follow up.

Univariate analysis was performed using the Centers for Disease Control software program EPI-Info. ${ }^{13}$ To control for potential confounders, logistic regression, performed with generalised linear interactive modelling (GLIM), ${ }^{14}$ was used to estimate the relative risk of contemplating stopping.

\section{Results}

During the study period 1140 inmates left Dane County jail and 578 left Rock County jail through each main booking office. Of these, 455 in Dane County and 351 in Rock County were incarcerated for three or more days. Questionnaires were returned by $376(83 \%)$ inmates in Dane County jail and by $289(82 \%)$ inmates in Rock County jail.

The distributions of age, sex, race, and employment status were similar in the respondents in the two jails (table 1). Inmates in Dane County had a shorter length of stay and more years of education. An equal proportion of inmates from both jails was allowed to go out to work (and therefore had access to cigarettes) during the daytime as a part of a work release programme. Inmates in Dane County were less accepting of the jails smoking policy. Inmates in the two jails had similar reasons for arrest (data not shown).

Rates of ever and current smokers were the same in the two jails (table 2). Among smokers at the time of arrest, those in Dane County had previously tried more often to stop smoking than had those in Rock County. More smokers planned to stop in Dane County than in Rock County. Finally, smokers from Dane County jail were more likely to contemplate stopping smoking after leaving the jail $(21 \% v 7 \%)$.

We next compared contemplation to quit rates by selected characteristics (table 3 ). Smokers who had tried to stop in the past and younger people were more likely to contemplate stopping smoking in both jails. Race, sex,

Table 1 Selected characteristics of prisoners in Dane and Rock County jails, Wisconsin, USA, 1990

$\begin{array}{cc}\text { Dane } & \text { Rock } \\ \text { County } & \text { County } \\ (n=376) & (n=289)\end{array}$

Mean age (years)

Sex (male) $(\%)$

Race (white) $\%$

Unemployed $\%$ )

Education ( $<12$ th grade) $(\%)$

Length of stay (days):

Mean

Median

On work release $(\%)$

Don't like the jail smoking policy $(\%)$

$\star \mathrm{p}<0.05$. 
Table 2 Smoking status of prisoners in Dane and Rock County jails, Wisconsin, USA, 1990

\begin{tabular}{|c|c|c|}
\hline & $\begin{array}{l}\text { Dane } \\
\text { County }\end{array}$ & $\begin{array}{l}\text { Rock } \\
\text { County }\end{array}$ \\
\hline No of respondents & 376 & 289 \\
\hline Ever smokers (\%) & 80 & 78 \\
\hline Current smokers $(\%)$ & 72 & 72 \\
\hline Current smokers & 270 & 208 \\
\hline Mean age of start (years) & 15 & 15 \\
\hline $\begin{array}{l}\text { Mean number of cigarettes } \\
\text { smoked per day }\end{array}$ & 22 & 23 \\
\hline Ever quit smoking for $\geqslant 1$ day $(\%)$ & 61 & $47^{\star}$ \\
\hline Would like to quit if easy (\%) & 44 & 44 \\
\hline Plan to continue to smoke $(\%)$ & 78 & $91^{\star}$ \\
\hline Plan to quit $(\%)$ & 9 & $3 \star$ \\
\hline Don't know if they will quit ( $\%)$ & 13 & $6^{\star}$ \\
\hline Contemplators to quit ${ }^{\star \star}(\%)$ & 21 & $7^{\star}$ \\
\hline
\end{tabular}

$\star \mathrm{p}<0.05$

$\star \star$ Smokers who were planning to stop smoking after release

or who did not know but would like to stop.

Table 3 Relative risk of contemplating stopping smoking ${ }^{\star}$ by selected characteristics, Dane and Rock County jails, Wisconsin, USA, 1990

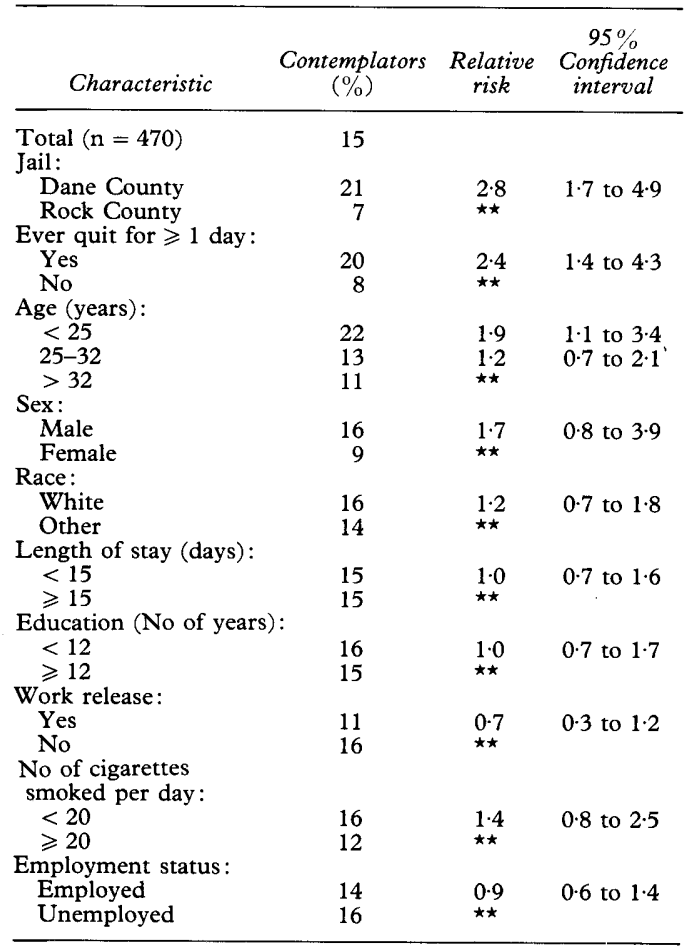

* Smokers who were planning to stop smoking after release or who did not know but would like to stop.

$\star \star$ Reference group.

level of education, work release status, reason for arrest, length of imprisonment, employment status, and daily cigarette consumption before imprisonment were not related to contemplating stopping smoking.

The relative risk for being a contemplator in Dane County jail compared with Rock County jail was still raised after the data were stratified by age and by previous attempts at stopping. When age, sex, race, length of imprisonment, work release status, daily cigarette consumption, previous attempts to stop, employment status, jail, and reason for arrest were included in a logistic regression model, only age and jail were significant predictors of contemplating stopping smoking. In this model the relative risk of contemplating stopping smoking in Dane County jail after the data were adjusted for age and previous attempts at stopping was $4 \cdot 1$ (95\% confidence interval $2 \cdot 0$ to $8 \cdot 0$ ).

We followed up 47 of the $63(75 \%)$ contemplators from Dane County jail and eight of the $15(53 \%)$ from Rock County jail. Eight $(17 \%)$ of the respondents from Dane County and one $(12 \%)$ from Rock County stated that they had not resumed smoking after their release. Of those who resumed smoking, $22(56 \%)$ from Dane County and one $(20 \%)$ from Rock County jail did so the same day they were released. Based on these data, we estimate that about $3 \%$ of smokers stopped smoking after leaving Dane County jail - that is, eight out of 270 smokers - while less than $1 \%$ did so after leaving Rock County jail.

\section{Discussion}

Smokers leaving a jail where smoking was not allowed were three to four times more likely to consider stopping smoking than were smokers leaving a jail where smoking was allowed. This association was independent of other factors and seemed to be due to the effects of different smoking policies in the two jails. After experiencing and overcoming nicotine withdrawal symptoms, inmates discharged from Dane County jail seemed to be more likely to consider stopping (or extending voluntarily what had been a forced abstinence) after their release.

Younger smokers in both jails were more likely to contemplate stopping smoking than were older smokers. This finding agrees with the findings of previous studies, in which younger smokers in the general population were more likely to consider stopping smoking. ${ }^{6}$

The proportion of smokers from Dane County jail who reported stopping smoking was about three times that of smokers from Rock County jail. However, as the number of observations in follow up was low and as we could not validate the self reported nonsmoking status, our results can only suggest an effect of the restrictive smoking policy on the rate of stopping.

Our study has some limitations. Firstly, some of the inmates were missed during the survey and follow up, with the possible introduction of a selection bias. The way prisoners are released (through different processes, around the clock, and from different sites) made it impossible to distribute a questionnaire to all of them. We have no reason to believe that the prisoners who did not receive a questionnaire differed from those who did in their smoking status or intention to stop smoking. A thorough comparison of many sociodemographic characteristics of these two groups showed no significant differences. Also, a quarter of the prisoners in both jails refused to fill out the questionnaire. The main reason for missing prisoners at follow up seemed to be their high mobility after release; many of them did not have a permanent address, and several were reported by relatives to be back in jail or prison. 
Secondly, the comparison jail had some smoking restrictions, though limited. If smoking restrictions have an effect on the desire to stop smoking after release from prison, the effect would have been more obvious if the comparison jail had no restrictions at all.

Finally, we were able to follow up contemplators after only two weeks from the day of their discharge. An assessment of their smoking status after a longer time could have been a more accurate measurement of their success in stopping, but this was not feasible.

To our knowledge, this is the first study of the effects on smokers of a restrictive smoking policy in a correctional institution. Smoking and smoking cessation have been described as cyclical, continuous processes. ${ }^{6}$ Our study suggests that a restrictive smoking policy may have the effect of moving smokers from a precontemplation stage (when smokers do not consider stopping soon) to a contemplation stage (when smokers are willing to stop), and possibly to a stopping stage. Another study has shown that smokers who are in a contemplation stage are more likely to stop smoking sometime in their lives. ${ }^{12}$ Further studies will have to assess to which extent our results can be generalised to longer term prisoners.

Most of the prisoners in our study who were contemplators either never stopped smoking or resumed smoking within a few days. In general, prisoners who smoke come from segments of the population in which smoking is more prevalent. Without any further support, the vast majority of them are likely to be unsuccessful in this attempt to stop smoking.

If these results are confirmed by future studies, setting restrictive smoking policies may have important public health implications. Smoking cessation counselling and help for prisoners has already been recommended because of the health risks of smoking and of exposure to ETS. ${ }^{15}$ The American Medical Association has recommended to the National Commission on Correctional Health Care that smoking cessation counselling be made a national standard for medical treatment in local jails and state and federal prisons. ${ }^{10}$ These programmes could be integrated into other drug or alcohol addiction programmes, where existing; they should be thoroughly tested and modelled based on the specific characteristics of the target population.
Our results add one more reason to recommend such programmes: smokers leaving a correctional institution after abstaining from cigarettes may be more willing to stay off cigarettes. These persons are often hard to reach through conventional smoking cessation programmes; if they receive some support before and after their release, they may be more likely to stop smoking successfully.

We are grateful to Dr Seth L Emont, Office on Smoking and Health, Centers for Disease Control, Atlanta, for his comments and help in this study. We thank Noreen Schmidt and Karen Dixon (Wisconsin Division of Health) for their help with data Dixon (Wisconsin Division of Health) for their help with data Officer); Rick F Raemisch, Sheriff; David L Listug, Joseph M Officer); Rick F Raemisch, Sheriff; David L Listug, Joseph M Norwick (Dane County Sheriff Department); Joe Black, Sheriff; Ronald Loveland (Rock County Sheriff Department); and the deputy sheriffs and staff from the Dane County and the support. Finally, we thank the prisoners who, through their cooperation, made this study possible.

1 Bureau of Justice Statistics. Correctional populations in the United States, 1989. Washington, DC, US Department of Justice, Bureau of Justice Statistics, 1991. (Publication No NCJ-130445.)

2 Romero, CA, Connell FA. A survey of prison policies regarding smoking and tobacco. Fournal of Prison and fail Health $1988 ; 7(1)$.

3 Salive ME, Smith GS, Brewer TF. Death in prison: changing mortality patterns among male prisoners in Maryland, 1979-87. Am J Public Health 1990; 80: Maryland

4 National Research Council. Environmental tobacco smoke: measuring exposure and assessing health effects. Washington, DC: National Academy Press, 1986.

5 Steenland $\mathrm{K}$. Passive smoking and the risk of heart disease. FAMA 1992; 267: 94-9.

6 Centers for Disease Control. Reducing the health consequences of smoking : 25 years of progress. A report of the Surgeon General, 1989. Rockville, Maryland: US Department of Health and Human Services, Public Health Service, 1989. (DHHS publication No (CDC) 89-8411.)

7 Skolnick A. While some correctional facilities go smokefree, others appear to help inmates to light up. $\mathscr{f} A M A$ 1990; $264: 1509-13$.

8 Cohen F. Exposure to secondary smoke survives 8th amendment attack. Correctional Law Reporter 1991; 3: amen

9 Himelstein L. Supreme Court plans to consider prisoner's right to smoke-free cell. Legal Times 1992 July $6: 13$.

10 American Medical Association. Priority briefing for medicine's leaders. This Week 1992 March $2 ; 2$ (7): 2 . (Newsletter of the AMA, Chicago, Illinois, USA.)

11 Centers for Disease Control. Cigarette smoking bans in county jails - Wisconsin, 1991. MMWR 1992; 41: 101-3.

12 Prochaska J, Di Clemente CC. Stages and processes of selfchange of smoking: toward an integrative model of change. fournal of Consulting and Clinical Psychology 1983; 51: 390-5.

13 Dean AD, Dean JA, Burton JK, Dicker RC. Epi Info, version 5: a word processing, database, and statistics program for epidemiology on microco

14 Royal Statistical Society. The GLIM System Release 3.77 manual. Oxford: Numerical Algorithms Group, 1985.

15 American Public Health Association. Reducing smoking in prisons and jails - American Public Health Association resolution. The Nation's Health 1991 Sept. 


\section{Translations of abstract}

\section{Influence de l'interdiction de fumer sur des prisonniers, dans le Wisconsin, Etats Unis}

Gianfranco Pezzino et al

\section{Résumé}

Objectif: Evaluer l'influence des interdictions de fumer en prison sur le comportement tabagique des prisonniers.

Conception: Une étude comparative a été menée auprès des détenus d'une prison où il était interdit de fumer et d'une prison où il était permis de fumer. Les prisonniers répondaient à un questionnaire au moment de leur libération. Les fumeurs qui déclaraient avoir l'intention d'arrêter de fumer après leur sortie de prison étaient recontactés par un courrier ou au téléphone, deux à quatre semaines plus tard.

Population: 376 prisonniers à leur sortie de la prison sans tabac et 288 prisonniers à leur sortie de l'autre prison, après un séjour de 3 jours ou plus.

Principale information recherchée: L'éventualité que les fumeurs envisagent à leur sortie de prison d'arrêter de fumer. On vérifiait auprès de ceux qui avaient indigué leur intention d'arrêter de fumer si c'était le cas deux à quatre semaines après leur sortie de prison.

Résultats: Les fumeurs ayant séjourné dans la prison sans tabac étaient 3 fois plus nombreux à envisager d'arrêter de fumer que les autres $(21 \%$ contre $7 \%$ ). Plus de $80 \%$ des prisonniers, des deux prisons, qui avaient envisagé d'arrêter, avaient recommencé ou n'avaient pas cessé deux semaines après leur sortie.

Conclusions: Lorsqu'ils quittent une prison sans tabac, les prisonniers fumeurs semblent plus désireux d'arrêter de fumer que ceux qui ont séjourné dans une prison où l'on peut fumer. Cela pourrait fournir une occasion de toucher cette population souvent difficile à joindre, par le biais d'un programme de sevrage et pourrait accroître leur chance d' arrêter de fumer lors de leurs tentatives ultérieures. Sans soutien extérieur, la plupart de ces personnes n'arrêteront jamais de fumer ou recommenceront rapidement à fumer.

\section{Repercusiones de la prohibición de fumar en prisioneros de Wisconsin, Estados Unidos}

Gianfranco Pezzino et al

\section{Resumen}

Objetivo: Evaluar las repercusiones de la norma que prohibe fumar en ciertas prisiones sobre las actitudes y comportamientos de los prisioneros con respecto al tabaquismo.

Diseño: Estudio de observación prospectivo en una prisión donde no se permite fumar y en otra donde sí se permite. Los prisioneros completaron un cuestionario en el momento de ser liberados. Los fumadores que declararon que no fumarian después de salir de la prisión fueron contactados por teléfono o por carta entre 2 y 4 semanas después.

Sujetos: 376 prisioneros dejaron la prisión donde no se permitía fumar y 289 dejaron la prisión donde sí se permitía, ambos grupos al cabo de una estadía de 3 o más días.

Medida principales de desenlace: Probabilidad de que los fumadores que dejaban cada prisión se propusieran (planearan o consideraran) dejar de fumar. Entre 2 y 4 semanas después de la liberación, se determinó la situación con respecto al tabaquismo de los que se proponian dejar de fumar, según su propia declaración. Resultados: Los fumadores que dejaron la prisión donde no se permitía fumar tenían cerca de tres veces más probabilidades que los otros de proponerse dejar el tabaquismo ( $21 \%$ frente a $7 \%, \mathrm{p}<0,001)$. El ajuste de los datos para tener en cuenta los posibles factores de confusión no modificó los resultados. Más de $80 \%$ de los individuos de ambas prisiones que estaban pensando en dejar el tabaquismo no lo suspendieron o lo reanudaron 2 semanas después de salir de la cárcel. Conclusiones: Parece que los fumadores que dejan una prisión donde no se permite fumar tienen un deseo mayor de abandonar el tabaquismo. Esto puede brindar la oportunidad de concentrar la atención de los programas de cesación del tabaquismo en estos fumadores, a los que no suele tenerse acceso, y aumentar asi las probabilidades de que tengan éxito en sus futuros intentos por abandonar el tabaquismo. Sin apoyo, la mayoria de estas personas nunca tratarán de dejar de fumar o pronto reanudarán el tabaquismo.

\section{威斯康星州无烟政策对狱中犯人的影响 吉安弗兰科・派几若}

研究目的：评价监狱中的限制吸烟政策对犯人的吸烟行为及态度的影响。

研究设计: 在一座无烟监狱和一座准许吸烟的监狱中同时实施前瞻性观察研究。犯人出狱时 填写一份调查表, 对那些宣称自己将来不吸烟的人在 2-4 周后, 进行电话跟踪或信访。 研究对象：376 名从无烟监狱中出狱；289名从对照监狱中出狱 (他们在狱中全少停留 3 天以 上。

主要结果指标: 两组人群在出狱后计划戒烟的叮能性。在出狱 2-4 周后, 那些计划戒烟的人 吸烟状况。

研究结果: 在从无烟监狱出狱的吸烟者中, 计划找烟的人数大约是准许吸烟的监狱计划找烟 人数的三倍 (分别为 $21 \%$ 和 $7 \%, \mathrm{P}<0.001$ )。针对潜在混淆因素所进行的数据调整并未攻变 此研究结果。两个监狱的出狱者中计划戒烟的人有 $80 \%$ 以上。出狱者似丞有更强的戒烟愿 望。这可能为在这些往往很难接触到吸烟者中州展戒烟项目提供了机会, 并提高他们将来戒 烟的可能性。没有外界的支持, 这些人绝大多数将永远不会努力戒烟或即使戒烟往往很快又 重新吸烟。 